into a normal position rapidly-one-third at once, one-third at the end of a week, and the remaining one-third at the end of the second week. He mentioned the tendo Achillis, and such a case of contraction of one tendon alone very well exemplified his point. Mr. Marsh distinctly referred to this Ispid reduction as an improvement on the old slow process, and yet as distinct from the "immediate method," of which he stated he had not sufficient experience to form an opinion. This led me to give my experience of the latter plan of operation, but I was not conscious of any dispute occurring.

Mr. Parker's letters seem to aim at introducing other matters, and they confuse the point which was first discussed. His plan of cutting the ligaments is a valuable addition to our means of reducing some of the severe forms of clubfoot; but this is quite another subject, and does not bear at all upon the question as to how quickly reduction of a deformity, when depending upon contracture of muscles, may be safely effected after the tendons of those muscles are divided.

I am, Sirs, yours faithfully,

Queen Anne-street, March, 1888.

Noble Smith.

* * The point raised in the above controversy has now, we think, been sufficiently discussed.-ED. L.

\section{PIT BURIAL NEAR GLASGOW.}

\section{To the Editors of THE LANCET.}

SIRS,-- Your Glasgow correspondent in THE L LANCET of last week gives, at p. 601, a very shocking description of Dalbeth Cemetery, and appears to be under the impression that there is no remedy for such a state of things. It is not the first time that I have heard of this scandalous mode of pit burial near Glasgow. In the Public Medicine Section of the British Medical Association held in Dublin last August, I read a paper on the disposal of the dead, and in the discussion which followed a member from Glasgow described a mode of pit burial he had witnessed near his city, and which strikingly resembled that of your correspondent, though I cannot be sure that it was actually the same cemetery. In replying, I told him that complaint should be made to the Home Secretary, who would no doubt direct an inquiry to be made. One of the members for Glasgow should be moved to ask a question in the House of Commons; for assuming, as I am sure we may, that your correspondent has not overstated the facts, such a state of matters is scandalous, and calls for immediate reform. I am, Sirs, yours faithfully,

Liverpool, March 24th, 1888. FRED. W. LOWNDES,

\section{RABIES IN DEER.}

To the Editors of THE LANCET.

SiRs, - With regard to the recent outbreak of rabies among the deer in Richmond Park, alluded to in THE LANCET of the 17th inst. (page 542), and to its being an unrecognised development of that malady, will you kindly allow me to state that this was not the first well-authenticated instance of rabies occurring among deer in this country. In "Rabies and Hydrophobia" (page 48) will be found an account of such an occurrence in 1856, at Stainborough, near Barnsley, in which many deer died with symptoms the same as those exhibited by the Richmond Park deer. Rabies was prevalent among dogs at the same time in the same locality, and people were bitten, great alarm being the result.

I am, Sirs, yours obediently,

March 22nd, 1888. GEORGE Fleming, F.R.C.V.S.

\section{NORTHERN COUNTIES NOTES.}

(From our own Correspondent.)

THE "SWEATING" SXSTEN IN NEWCASTLE.

THE "sweating" system of tailoring has been frequently vigorously attacked in THE LANCET, but we never knew until quite lately that it had got any footing in the north. Thanks, however, to an influential public meeting held in Newcastle last week under the presidency of the Mayor, we know a good deal about it now, and the more we know of it the less we like it. Its condemnation by medical and other speakers was very pronounced, and this was followed by the unanimous voice of a very large meeting. One of the speakers (Mr. Councillor Laird) stated " that it was of very recent date that the system had been introduced into Newcastle, and that there were certain parts of the town where it was carried out to perfection. In the greater number of instances female labour was employed for the purpose of making a garment as cheap as possible in order to compete successfully with legitimate workmen. The hours they worked were unlimited. There were several places of that kind in Newcastle. He was within bounds in saying there were a dozen places in which, if they went in at $8,9,10$, or 11 o'clock at night, they would see these poor creatures toiling away." I believe myself that a practice so utterly opposed to all sanitary knowledge will not last long here but there will be a public demand for a more stringent enforcement of the Workshops and Factories Regulation Act. It was shown that the provisions of this Act were, under the operation of the "sweating" system, most systematically and regularly evaded.

ACCIDENTS IN NORTHERN MINES.

The Newcastle Chronicle has published the annual preliminary summary of official mineral statistics, and the reference to accidents in northern mines is interesting. The total loss of life in mines in the north under the Coal Mines Act has been as follows:-

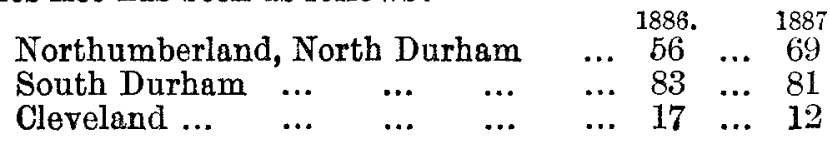

The increased loss of life in the first-nomed district is largely due to the explosions of fire-damp. In South Durham the loss through explosions declines, but that through miscellaneous accidents underground increases, and in Cleveland the decrease is chiefiy ascribable to less fatal falls in mines. Relatively to the number of persons employed in and about mines, Northumberland district showed rather worse, and those in South Durham and Cleveland increased in safety. Both the coal-producing districts named, however, are above the average in regard to safety in proportion to men employed. The metalliferous mines employed 600 more persons, both maleand female; the number of lives lost in this class decreased, and a lower average was exhibited.

\section{SUNDERLAND,}

It is not surprising that small-pox has been imported into Sunderland from Spain. Three mild cases were found on board a steamer which came from Bilbao. The medical officer of health became aware of the cases, and he (Mr. A. E. Harris) had them immediately taken to the small-pox hospital at the workhouse, the new infectious diseases hospital for the borough not being completed yet, although it is time and very desirable it should be ready, seeing the special risk that Sunderland runs from importation of disease. I hear that a gentleman in the town has since taken the disease from a relative who had come from Spain, and he had died rather suddenly from it. The number of patients entered at the Sunderland Provident, I Isspensary during the past year amounted to 1439 ; prescriptions dispensed, 22,672 ; visits by medical staff to patients at wheire own homes, 1400. Number of consultations held at sorrgeries of medical otficers, 12,500 ; and at the dispensary, 3133 . At Gateshead Dr. Purdie has received a hand some presentation from the ladies attending the St. John Ambuiance "first aid" classes, together with an expression of thanks for his admirable and painstaking instruction. Newcastie-on-Tyne, March 26th.

DUBLIN.

(From our own Correspondent.)

MEDICAL INSPECTORSHIP, LOCAL GOVERNMENT BOARD,

IT is currently reported that Dr. E. C. Thompson, of Omagh, has been appointed a medical inspector of the Local Government Board in the vacancy caused by the promotion of Dr. O'Farrell. Dr. Thompson is surgeon to the Tyrone County Infirmary and Gaol, and visiting physician to Tyrone and Fermanagh District Lunatic Asylum, and his professional 